\title{
Effects of cassava meal on carcass characteristics and cholesterol of growing pig
}

${ }^{1 *}$ Adeyemi, M. A. and ${ }^{2}$ Akinfala, E. O.

${ }^{I}$ Department of Animal Production and Health, Ondo State University of Science and

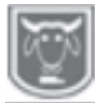
Technology, Okitipupa

${ }^{2}$ Department of Animal Sciences, Obafemi Awolowo University, Ile-Ife

*Corresponding author: ade_maxwell@yahoo.com; +234 7063055036

\section{Abstract}

Twenty growing pigs with an average initial weight of $20.00 \pm 0.5 \mathrm{~kg}$ were randomly assigned to five dietary treatments in a completely randomized design with two replicates per treatment and two animals in each replicate. Cassava Plant Meal (CPM) prepared from sundried unpeeled cassava tubers, leaves and tender cassava stems, mixed at ratio 3:1 of unpeeled tuber meal to cassava leaf meal plus tender stem meal with the ratio of cassava leaf meal to tender stem meal as 5:1 was included in balanced rations at graded levels of 0, 25, 50, 75 and 100 percent in a fifty-six days feeding trials. The experimental pigs were weighed before and after slaughtering, dressing percent was evaluated and carcass length and back fat depth were measured on treatment basis. Meat samples were collected at the ribs $\left(2^{\text {nd }}\right.$ and $3^{\text {rd }}$ and also $12^{\text {th }}$ and $13^{\text {th }}$ ) for cholesterol analysis. The $50 \%$ CPM diet produced the heaviest slaughter weight. There was no significant $(p>0.05)$ difference in the dressing percentage of pigs across dietary treatments although pigs on the control diet dressed well while pigs on $100 \%$ CPM dressed the poorest. The $100 \%$ CPM diet induced the leanest carcass. All the carcass and organ measurements were significantly $(p<0.05)$ affected by dietary treatments. There was non-significant $(p>0.05)$ influence of dietary treatments on total and high density lipoprotein cholesterol although the $50 \%$ CPM diet produced the least and highest values respectively. Low density and very low density lipoprotein cholesterol were significantly ( $p$ $<0.05)$ affected by dietary treatments. Replacement of maize by varying levels of cassava plant meal diets enhanced production of leaner carcass.

Keywords: Alternative feedstuff; low-fat pork; maize

\section{Introduction}

The exorbitant price and marked shift in availability of conventional feed ingredients particularly dietary energy source for the pig industry (Kozera et al., 2016) implied exploring a wider range of alternative feedstuffs in formulating diets for pigs. Cassava and its products have received attention from swine nutritionist. Globally, cassava production is estimated at 281.1 million metric tonnes with Nigeria as the leading producer (56.8 million metric tonnes) in 2016 (FAO Outlook, 2016). Cassava has been found to be a multipurpose crop that can thrive in almost every soil and be relied upon to provide the desired relief against the escalating cost of livestock feeds (Tewe, 1997). However, cassava root meals are deficient in essential amino acids such as methionine, lysine and cysteine (Motagnac et al., 2009; Omede et al., 2018). The option to improve the nutritional profile of cassava meal at reduced cost necessitated the development of composite cassava plant meal (sun-dried unpeeled tubers + leaves + tender cassava stem) as suitable replacement for maize in the diets of pigs (Akinfala and Tewe, 2001). In Nigeria, cassava is presently underutilised particularly, the leaves and tender stems as they are often left to rot away in farms and homesteads after harvesting the value-giving component (Akinfala et al., 2013). The development of composite cassava meal was in an attempt to balance the high crude protein, bulk, minerals and vitamins of leaves and tender stem with the energy-rich component of the roots. 


\section{Effects of cassava meal on carcass characteristics and cholesterol of growing pig}

Previous studies have established standardised composite cassava plant meal as an acceptable energy source in the diets of growing pigs (Adeyemi and Akinfala 2018). The effects on organ weights, carcass cholesterol and characteristics have not been fully documented. However, research has revealed conflicting results on the replacement of cereal grains by graded levels of cassava meals. Onyimonyi and Okeke (2005), Aro and Akinjokun (2012) observed significant depressing effects on live weight and carcass characteristics. Studies by Sonaiya et al. (1982) and Lekule et al. (2007) on the effects of dietary cassava on carcass fat and characteristics revealed reduced back fat with no deleterious effects on the carcass quality as the levels of inclusion of cassava meals increased. The cassava variety used, age and the length at harvest of tender cassava stem that formed the composite cassava meal may be the possible causes of the observed variations. Therefore, this study was undertaken to obtain more information on the efficiency of replacing maize with standardised composite cassava plant meals in the diets of growing pigs for organ weights, carcass cholesterol and characteristics with the possibility of contributing to innovative development and appropriate use of alternative feed options for pigs.

\section{Materials and methods \\ Experimental location and preparation of ingredients}

The experiment was carried out at the Swine Unit of the Teaching and Research Farm, the Poultry Meat Laboratory of the Department of Animal Sciences, Obafemi Awolowo University (OAU), Ile-Ife, Nigeria and the laboratory of the Department of Animal Science, University of Ibadan, Nigeria. The cassava tubers of tropical Manihot Species (TMS 30572) aged 24 months were purchased from local farmers near the OAU Teaching and Research Farm. Soil was shaken off the lifted cassava tubers, washed and sliced into pieces. The cassava leaves were harvested from the plant stem and the tender stems were harvested at $5 \mathrm{~cm}$, usually 6 to 7 nodes from the top of the plant. The tubers, leaves and tender stems were sundried on concrete floors for about 7 to 8 days with daily turning, depending on the intensity of the sunlight. They were then milled using a grinding machine with 0.3 $\mathrm{mm}$ sieve. The composite cassava plant was mixed in line with the procedure of Akinfala et al. (2002) but at a higher ratio of $3: 1$ so as to have a comparable minimum crude protein content of $10 \%$ as maize.

The proximate analysis, hydrocyanic acid and energy contents of maize and cassava plant meal appear on Table 2. The moisture, crude protein, fibre, ash and ether extract were analysed by the methods of AOAC (2005). Metabolizable energy was determined using the methods of Pauzenga (1985) and HCN content was determined by the modified alkaline picrate methods of Onwuka (2005).

\section{Experimental animals and design}

Twenty growing crossbred (Large White $\mathrm{x}$ Hampshire) pigs of average initial weight of $20.00 \pm 0.50 \mathrm{~kg}$ were randomly allocated into five dietary treatments and each treatment was replicated twice and housed in groups of 2 (same sex) based on body weight in a concrete floor pen. The experiment was completely randomised design.

\section{Experimental diets and management of experimental units}

A basal diet of $18 \%$ crude protein was formulated with $50 \%$ maize. The maize was then replaced with the composite cassava plant meal (CPM) at rates of 0,25 , 50, 75 and $100 \%$ in the five CPM experimental diets (Table 1). All the diets contained the same amount of other ingredients. The pigs were group-fed and 


\section{Adeyemi and Akinfala}

allowed ad libitum access to the diets and water was made available in concrete feeding and watering troughs for a period of eight weeks. The pens were regularly cleaned daily while vaccination and medication schedules were strictly followed. At the end of the experiment, animals were weighed before and after slaughtering to evaluate the dressing percent.

Table 1: Proximate, HCN and Energy contents of maize and cassava plant meal

\begin{tabular}{lcc}
\hline \multicolumn{1}{c}{ Parameters (\%) } & \multicolumn{2}{c}{ Test ingredients } \\
Maize & CPM \\
\hline Dry Matter & 88.1 & 90.1 \\
Crude Protein & 10.4 & 12.5 \\
Crude Fibre & 2.6 & 6.8 \\
Ash & 2.8 & 6.2 \\
Ether Extract & 4.5 & 3.3 \\
NFE & 67.8 & 61.3 \\
HCN (ppm) & ND & 55.0 \\
M E (kcal/kg) & $3,156.1$ & 2963.1 \\
\hline
\end{tabular}

NFE- Nitrogen Free Extract, ME- Metabolizable Energy

Table 2: Composition of experimental diets for feeding growing pigs

\begin{tabular}{lccccc}
\hline & \multicolumn{5}{c}{ Cassava levels (\%) } \\
\cline { 2 - 6 } Ingredients (\%) & $\mathbf{0}$ & $\mathbf{2 5}$ & $\mathbf{5 0}$ & $\mathbf{7 5}$ & $\mathbf{1 0 0}$ \\
\hline Maize & 50.0 & 37.5 & 25.0 & 12.5 & - \\
Cassava plant meal & - & 12.5 & 25.0 & 37.5 & 50.0 \\
Groundnut cake & 10.0 & 10.0 & 10.0 & 10.0 & 10.0 \\
Soybean meal & 8.0 & 8.0 & 8.0 & 8.0 & 8.0 \\
Palm kernel cake & 25.0 & 25.0 & 25.0 & 25.0 & 25.0 \\
Fish meal & 2.0 & 2.0 & 2.0 & 2.0 & 2.0 \\
Bone meal & 1.50 & 1.50 & 1.50 & 1.50 & 1.50 \\
Oyster shell & 3.0 & 3.0 & 3.0 & 3.0 & 3.0 \\
* Premix (Vitamin-Mineral) & 0.25 & 0.25 & 0.25 & 0.25 & 0.25 \\
Salt & 0.25 & 0.25 & 0.25 & 0.25 & 0.25 \\
Total & 100.0 & 100.0 & 100.0 & 100.0 & 100.0 \\
\hline Calculated Analysis & & & & & \\
Metabolizable Energy (Kcal/kg) & 2798.1 & 2739.8 & 2681.5 & 2623.2 & 2564.9 \\
Crude protein (\%) & 18.72 & 18.69 & 18.66 & 18.63 & 18.61 \\
Crude fibre (\%) & 5.17 & 5.58 & 6.01 & 6.43 & 6.86
\end{tabular}

*Premix (Vit/Min): vitamin A 10,000,000 IU; vitamin D 32,000,000 IU; vitamin E 8,000 IU; vitamin K 2,000 mg; vitamin B1 2,000 mg; vitamin B2 5,500 mg; vitamin B61,200 mg; vitamin B12 $12 \mathrm{mg}$; biotin $30 \mathrm{mg}$; folic acid $600 \mathrm{mg}$; niacin 10,000 mg; pantothenic ac id 7,000 mg; choline chloride 500,000mg; vitamin C 10,000 mg; iron 60,000 mg; Mn 80,000 mg; Cu $800 \mathrm{mg}$; Zn 50,000 mg; iodine 2,000 mg; cobalt $450 \mathrm{mg}$; selenium $100 \mathrm{mg} ; \mathrm{Mg}$ 100,000 mg; anti-oxidant 6,000 mg.

\section{Evaluation of carcass cholesterol and characteristics}

At the end of the experiment, two animals per treatment were sacrificed for carcass analysis. Records of live weight, weights of carcass, organs (lung, kidney, liver and spleen), empty stomach, head, loin, Ham and shoulder were determined using calibrated weighing scale. The length of carcass and back fat depth were taken on treatment basis using graduated tape rule and plastic metre rule respectively. Meat samples were collected between the second $\left(2^{\text {nd }}\right)$ and third $\left(3^{\text {rd }}\right)$ ribs and also the twelfth 


\section{Effects of cassava meal on carcass characteristics and cholesterol of growing pig}

$\left(12^{\text {th }}\right)$ and thirteenth $\left(13^{\text {th }}\right)$ ribs for cholesterol analysis. The meat samples were saponified following the modified version of the methods described by Stewart et al. (1992). After saponification, samples were analysed by High Performance Liquid Chromatography (HPLC) using the procedure of Bragagnolo et al. (2001). Cholesterol identification was performed by co-chromatography and by comparing sample retention times with standard retention times (Sigma and Polyscience, U.S.A ${ }^{\circledR C}$ C6667). Cholesterol quantification was achieved by internal standardisation $(0.504 \mathrm{mg}$ for 6-ketocholestanol, Sigma and Polyscience, U.S.A. $\left.{ }^{\circledR K} 1250\right)$ using the external standard technique from a standard curve area vs. concentration.

\section{Statistical analysis}

The data were subjected to one-way Analysis of Variance (ANOVA) using the general linear model procedure of SAS (2009) while the differences in means were assessed at $p<0.05$ (95\% confidence) and separated using Duncan's Multiple Range Test.

\section{Results}

The results of proximate analysis, hydrocyanic acid and energy contents of maize and cassava plant meal are summarised in Table 1. There were similarities $(p>0.05)$ in the values obtained for the proximate composition of the CPM and maize. Higher values were obtained for the crude protein and ash contents of CPM than maize by $16.8 \%$ and $54.8 \%$ respectively. Also, for the crude fibre, ether extract and nitrogen free extract values for maize was $61.8 \%, 26.7 \%$ and $9.6 \%$ respectively better than cassava plant meal. The metabolizable energy content of maize was $6.12 \%$ higher than that of CPM although, CPM was found to favourably compare with maize.

Pigs on $50 \%$ CPM diet had the highest slaughter weight being $0.37 \%, 2.23 \%, 3.13$ $\%$ and $3.25 \%$ heavier than pigs on $0 \%, 25$ $\%, 75 \%$ and $100 \%$ CPM respectively (Table 3). Pigs on control diet had the highest dressing percentage being $2.11 \%$, $0.80 \%, 3.30 \%$ and $3.42 \%$ better dressed than pigs on $25 \%, 50 \%, 75 \%$ and $100 \%$ CPM respectively. Differences in carcass length were significant $(\mathrm{p}<0.05)$. Pigs on the control diets had $14 \%, 7 \%, 16 \%$ and 3 $\%$ increase in carcass length as compared with pigs on $25 \%, 50 \%, 75 \%$ and $100 \%$ CPM respectively. The longest pigs on control diet dressed well although the shortest pigs on $75 \% \mathrm{CPM}$ did not dress the poorest. There was correlation among the slaughter weight, dressing percentage and back fat depth. Significant $(p<0.05)$ difference existed across treatments for back fat depth. Pigs on $100 \%$ CPM diet showed $80 \%, 77 \%, 70 \%$ and $40 \%$ reduction in back fat depth as compared with pigs on $0 \%, 25 \%, 50 \%$ and $75 \%$ CPM diets respectively. Increasing CPM levels in the diets did not result in increased weights of the head, ham, loin and shoulder though the values were statistically significant $(\mathrm{p}<0.05)$ but did not follow any trend. There were significant $(\mathrm{p}<0.05)$ differences in the weights of all measured visceral organs (kidney, lung, spleen and heart) and empty stomach except for the liver. However, all these measurements did not follow any trend or showed impairment on the health status of the animals.

The total and high density lipoprotein cholesterol contents in pigs were not significantly influenced $(\mathrm{p}>0.05)$ by dietary treatment (Table 4). Pigs on $50 \%$ CPM diet produced the least total cholesterol while $100 \%$ CPM diets had the highest. Also, high density lipoprotein cholesterol followed the same trend and was $10 \%, 3 \%, 12 \%$ and $17 \%$ better than pigs on $0 \%, 25 \%, 75 \%$ and $100 \%$ CPM diets respectively. Control diet had the least low density lipoprotein (LDL) cholesterol 


\section{Adeyemi and Akinfala}

being $21 \%, 19 \%, 25 \%$ and $20 \%$ better than $25 \%, 50 \%, 75 \%$ and $100 \% \mathrm{CPM}$ diets respectively though the values are not significantly different $(\mathrm{p}>0.05)$. Also, there was no significant effect of dietary treatments on very low density lipoprotein (VLDL) cholesterol. Pigs on $50 \%$ CPM diet produced the least VLDL cholesterol while control diet had the highest value.

Table 3. Carcass characteristics and organ weights of growing pigs fed experimental diets

\begin{tabular}{|c|c|c|c|c|c|c|c|}
\hline \multirow[b]{2}{*}{ Parameters } & \multicolumn{6}{|c|}{ Cassava Levels (\%) } & \multirow[b]{2}{*}{$P$} \\
\hline & $\mathbf{0}$ & 25 & 50 & 75 & 100 & + SEM & \\
\hline Slaughter weight (kg) & 42.97 & 42.17 & 43.13 & 41.78 & 41.73 & 0.39 & 0.75 \\
\hline Dressing percentage & 76.0 & 74.4 & 75.4 & 73.5 & 73.4 & 1.05 & 0.94 \\
\hline Carcass length (cm) & $87.0^{\mathrm{a}}$ & $75.0^{\mathrm{b}}$ & $81.0^{\mathrm{ab}}$ & $73.0^{\mathrm{b}}$ & $84.0^{\mathrm{a}}$ & 1.93 & 0.04 \\
\hline Back fat depth (cm) & $2.45^{\mathrm{a}}$ & $2.21^{\mathrm{b}}$ & $1.68^{\mathrm{c}}$ & $0.83^{\mathrm{d}}$ & $0.50^{\mathrm{e}}$ & 0.25 & 0.01 \\
\hline$*$ Head & $5.90^{\mathrm{a}}$ & $4.90^{\mathrm{a}}$ & $4.55^{\mathrm{b}}$ & $5.00^{\mathrm{ab}}$ & $5.70^{\mathrm{a}}$ & 0.20 & 0.04 \\
\hline *Ham & $40.0^{\mathrm{ab}}$ & $38.4^{\mathrm{b}}$ & $39.5^{\mathrm{ab}}$ & $39.2^{\mathrm{ab}}$ & $41.6^{\mathrm{a}}$ & 0.46 & 0.04 \\
\hline *Loin & 18.53 & 24.56 & 23.61 & 23.61 & 22.59 & 0.28 & 0.03 \\
\hline *Shoulder & $37.1^{\mathrm{a}}$ & $37.0^{\mathrm{ab}}$ & $32.6^{\mathrm{b}}$ & $37.2^{\mathrm{ab}}$ & $35.8^{\mathrm{ab}}$ & 0.39 & 0.04 \\
\hline Kidney weight (g) & $260^{\mathrm{a}}$ & $200^{\mathrm{b}}$ & $200^{\mathrm{b}}$ & $200^{\mathrm{b}}$ & $250^{\mathrm{a}}$ & 9.12 & 0.01 \\
\hline Lung weight (g) & $500^{\mathrm{ab}}$ & $400^{\mathrm{bc}}$ & $400^{\mathrm{bc}}$ & $340^{c}$ & $600^{\mathrm{a}}$ & 32.52 & 0.01 \\
\hline Liver weight (g) & 1200 & 1000 & 900 & 1020 & 1100 & 40.0 & 0.24 \\
\hline Weight of spleen (g) & $200^{\mathrm{a}}$ & $100^{\mathrm{b}}$ & $100^{\mathrm{b}}$ & $80^{\mathrm{c}}$ & $200^{\mathrm{a}}$ & 17.67 & 0.01 \\
\hline Heart weight $(\mathrm{g})$ & $280^{\mathrm{a}}$ & $300^{\mathrm{a}}$ & $200^{\mathrm{b}}$ & $280^{\mathrm{a}}$ & $300^{\mathrm{a}}$ & 13.44 & 0.03 \\
\hline Weight of empty stomach $(\mathrm{g})$ & $500^{\mathrm{b}}$ & $680^{\mathrm{a}}$ & $600^{\mathrm{ab}}$ & $580^{\mathrm{ab}}$ & $650^{\mathrm{a}}$ & 24.62 & 0.02 \\
\hline \multicolumn{8}{|c|}{$\begin{array}{l}\text { Figures with the same super script are not significantly different }(\mathrm{p}>0.05) \\
\text { *expressed as percentage of carcass weight }\end{array}$} \\
\hline \multicolumn{8}{|c|}{ Table 4: Carcass cholesterol of growing pigs fed graded levels of cassava based diets } \\
\hline \multirow[b]{2}{*}{ Parameters (mg/100g) } & \multicolumn{5}{|c|}{ Cassava levels (\%) } & & \\
\hline & $\mathbf{0}$ & 25 & $\mathbf{5 0}$ & 75 & 100 & \pm SEM & $P$ \\
\hline Total cholesterol & 87.9 & 83.2 & 74.9 & 81.7 & 89.2 & 2.50 & 0.474 \\
\hline HDL Cholesterol & 32.6 & 35.5 & 36.4 & 32.1 & 30.1 & 1.12 & 0.426 \\
\hline LDL Cholesterol & $22.5^{\mathrm{b}}$ & $28.5^{\mathrm{a}}$ & $27.9^{\mathrm{a}}$ & $29.9^{\mathrm{a}}$ & $28.2^{\mathrm{a}}$ & 0.92 & 0.024 \\
\hline VLDL Cholesterol & $32.9^{\mathrm{a}}$ & $19.2^{\mathrm{b}}$ & $10.7^{\mathrm{c}}$ & $19.7^{\mathrm{b}}$ & $30.9^{\mathrm{a}}$ & 1.39 & 0.015 \\
\hline
\end{tabular}

HDL-High Density Lipoprotein, LDL-Low Density Lipoprotein, VLDL-Very Low Density

Lipoprotein

Figures with the same super script are not significantly different $(p>0.05)$

\section{Discussion}

This study indicates that cassava plant meals not only compare favourably with maize especially in terms of crude protein and energy content but that leaner carcass and slaughter weight are enhanced. Also, carcass characteristics, organ weights and cholesterol contents were not negatively affected. Results from the work of Akinfala et al. (2013) showed lower crude protein, fibre and ether extract for CPM. The variation in the proximate values of CPM obtained in this study compared to that of Akinfala et al. (2013) may be due to varietal difference (TMS 30572), age of cassava tubers and the length at harvest of tender stems ( $5 \mathrm{~cm}$ from the top of the plant).

The finding from the study of Sonaiya and Omole (1977) and Onyimonyi and Okeke (2005) showed reduction in back fat depth when graded levels of cassava peel meals were added to the diets of grower pigs. Herr 


\section{Effects of cassava meal on carcass characteristics and cholesterol of growing pig}

et al. (2000) attributed the proportional reduction in back fat depth to the reduction in dietary energy and increased dietary fibre of the diets fed to pigs. The weight of organs and empty stomach did not seem to follow any trend. This result agrees with the work of Onyimonyi and Okeke (2005). The authors fed cassava peel meals to growing pigs and found increasing weight of organs as the levels of cassava peels increased. The observed variations may be due to differences in the levels of HCN present in the cassava variety used. The total cholesterol and high density lipoprotein contents obtained in this study were not in agreement with the findings of Cannata et al. (2010) who reported that cholesterol in pork is influenced by fat depth, stage of maturity and diet composition. However, this result is consistent with the findings of Bragagnolo (2009) and Sinclair et al. (2010). The total cholesterol content obtained in this study fell within the range (30.00 $\mathrm{mg} / 100 \mathrm{~g}$ to $86.40 \mathrm{mg} / 100 \mathrm{~g}$ ) reported by Rubio (2006) for maize based diet. The values of total cholesterol content obtained in this study were lower than the recommended value $(119 \mathrm{mg} / 100 \mathrm{~g})$ reported by Honikel (1992) and Rourke et al. (1992). In all the measured cholesterol components, $75 \%$ CPM appears to produce the better value in respect of the total, HDL and VLDL cholesterol contents. The differences in the values obtained for the cholesterol content of the carcass was not influenced by the inclusion of CPM diets.

\section{Conclusions}

The study showed that replacing maize partially or totally with CPM in the diets of growing pigs reduced the back fat depth.

\section{References}

A.O.A.C. 2005. Association of Official Analytical Chemist, Official Methods of Analysis, $17^{\text {th }}$ Edn., Washington D. C.
Adeyemi, M. A. and Akinfala, E. O. 2018. Growth Response of Growing Pigs to Diets Containing Graded Levels of Cassava Plant Meal, in: proceeding of the $23^{\text {rd }}$ Annual Conference on Development of a Resilient Livestock Industry for National Economic Growth, Ilorin, Nigeria, 9 -13 September, 426-428.

Akinfala, E. O., and Tewe, O. O. 2001. Utilization of whole cassava plant by growing pigs in the tropics. Lives. Res. Rur. Dev. 13(43). Retrieved A pril 16,2018, from http://www.lrrd.org/lrrd13/5/akin13 5.htm

Akinfala, E. O. Aderibigbe, A. O. and Matanmi, O. 2002. Evaluation of the nutritive value of whole cassava plant meal as replacement for maize in the starter diets for broiler chickens. Lives. Res. Rur. Dev. 14(56). Retrieved April 16, 2018, from http://www.lrrd.org/lrrd14/6/akin14 6.htm

Akinfala, E. O., Adegbaju, S. W., and Ilori, J. O. 2013. Evaluation of the nutritive value of whole cassava plant as a replacement for maize in the diets of growing pigs in the tropics. Ife J. Agric. 26, 15-22.

Aro, S. O., and Akinjokun, O. M. 2012. Meat and carcass characteristics of growing pigs fed microbially enhanced cassava peel diets. Arch. Zootec. 61 (235), 407-414.

Bragagnolo, N. 2009. Cholesterol and cholesterol oxides in meat and meat products, In: Handbook of muscle foods analysis, edited by: Nollet, L. M. L., Toldra, F. , CRC Press, Florida, 187-219.

Bragagnolo, N., and Rodriguez-Amaya, D. B. 2001. Total lipid, cholesterol, and fatty acids of farmed freshwater prawn (macrobrachium rosenbergii) and wild marine shrimp (penaeus 


\section{Adeyemi and Akinfala}

brasiliensis, penaeus schimitti, xiphopenaeus kroyeri). J. Food Comp. Anal., 14,.359-369.

Cannata, S., Engle, T. E., Moeller, S. J., Zerby, H. N., Radunz, A. E., Green, M. D., and Bass, P. D. 2010. Effects of visual marbling on sensory properties and quality traits of pork loin. Meat Sci., 85(3), 28-34.

FAO Outlook. 2016. Food and Agriculture Organization Outlook, United Nations, Global Market Analysis. http://www.fao.org/docrep/011/ai47 4e/ai474e06.htm.

Herr, C. T., Kendall, D. C., Bowers, K. A., and Richert, B. T. 2000. Evaluating Variable Feed Energy Levels for Grow-finish Pigs. Department of Animal Sciences, Purdue University Swine day, August 31.

Honikel, K. O. 1992. Reference methods for the assessment of physical characteristics of meat. Meat Sci., 49(4), 447-457.

Kozera, W. J., Karpiesiuk, K., Bugnacka, D., Falkowski, J and Milewska, M. 2016. Production performance of pigs reared in different systems and fed increased energy contents diets with or without green alfalfa. South African Journal of Animal Science, 46 (1): 70 - 76.

Lekule, F. P., Shem, M. N., Laswai, G. H., Mutayoba, S. K., Sarwatt, S. V., Mtenga, L. A. and Malole, J. L. 2007. Nutritive value of fresh cassava tubers, cassava root meal and cassava chips for growing-finishing pigs, in: Proceedings of the $13^{\text {th }}$ ISTRC Symposium, 521 - 529.

Montagnac, J. A., Davis, C. R., and Tanumihardjo, S. A. 2009. Nutritional value of cassava for use as a staple food and recent advances for improvement. Com. Rev. Food Sci. Food Saf. Sci. Food Saf.,
8(3), 181-194.

Omede, A. A., Ahiwe, E. U., Zhu, Z. Y., Fru-Nji, F. and Iji, P. A. 2018. Improving cassava quality for poultry feeding through application o f b i o t e c h n o l o g y, DOI.org/10.5772/intechopen.72236.

Onwuka, G. I. 2005. Food Analysis and instrumentations and Practice. (Eds.). Napthali Prints, Surulere, Lagos, Nigeria, pp. 140-160.

Onyimonyi, A. E., and Okeke, G. C. 2005. Carcass, organ and pathological characteristics of grower pigs fed cassava peel meal. J. Agric. Food, Envir. Ext. 4(1), 1-4.

Pauzenga, U. 1985. Feeding parent stock. Zootec. Int'l., $22-24$.

Rourke, T. L., Ramsey, B. C., Davis, G. W., Clark, J. R., and Wheeler, T. L. 1992. Consumption and Plate Waste of Regular and Total Trim Roasted Pork Loins. J. Mus. F. 3, 341-354.

Rubio, L. A. 2006. Ileal digestibility of raw and autoclaved kidney bean (Phaseolus vulgaris) seed meals in cannulated pigs Anim. Sci. 81,125133.

SAS 2009. Statistical Analysis Systems User's Guide, version 9.1 for windows, SAS Institute, Inc.,Cary, NC, U.S.A.

Sinclair, A. J., Barone, S., Stobaus, T., Tume, R., Beilken, S., Muller, W., Cunningham, J., Barnes, J. A., and Greenfield, H. 2010. Lipid composition of Australian pork cuts 2005/2006. Food Chem., 121(3), 72 81.

Sonaiya, E. B., and Omole, T. A. 1977. Cassava peels for finishing pigs. Nut. Rep. Int'l., 16 (4), 479-486.

Sonaiya, E. B., Omole, T. A., and Adegbola, A. A. 1982. Effects of cassava meal diets on the Performance and Carcass 


\section{Effects of cassava meal on carcass characteristics and cholesterol of growing pig}

characteristics of Growing-finishing pigs. Nut Rep. Int'l., 26(3), 365-372.

Stewart, G., Gosselin, C., and Pandian, S. 1992. Selected ion monitoring of tertbutyldimethylsilyl cholesterol ethers for determination of total cholesterol content in foods, Food Chem., 44, $377-380$.
Tewe, O. O. 1997. Sustainability and Development: Paradigms from Nigeria Livestock Industry. In: Inaugural Lecture delivered on behalf of Faculty of Agriculture and Forestry, University of Ibadan, Ibadan, Nigeria. Ibadan: University of Ibadan, 1-37.

Received: $3^{\text {rd }}$ October, 2018

Accepted: 9 $^{\text {th }}$ February, 2019 